\title{
Effects of Different Soil Amendments on Mixed Heavy Metals Contamination in Vetiver Grass
}

\author{
Chuck Chuan $\mathrm{Ng}^{1}$ (D) Amru Nasrulhaq Boyce ${ }^{1} \cdot$ Md Motior Rahman $^{1,2}$. \\ Mhd Radzi Abas ${ }^{3}$
}

Received: 4 January 2016 / Accepted: 13 September 2016 / Published online: 21 September 2016

(C) Springer Science+Business Media New York 2016

\begin{abstract}
Three different types of low cost soil amendments, namely, EDTA, elemental S and N-fertilizer, were investigated with Vetiver grass, Vetiveria zizanioides (Linn.) Nash growing under highly mixed $\mathrm{Cd}-\mathrm{Pb}$ contamination conditions. A significant increase $(p<0.05)$ in $\mathrm{Cd}$ and $\mathrm{Pb}$ accumulation were recorded in the shoots of all EDTA and N-fertilizer assisted treatments. The accumulation of $\mathrm{Cd}$ in $25 \mathrm{mmol} \mathrm{EDTA} / \mathrm{kg}$ soil and $300 \mathrm{mmol} \mathrm{N} / \mathrm{kg}$ soil showed relatively higher translocation factor (1.72 and 2.15 ) and percentage metal efficacy (63.25\% and $68.22 \%$ ), respectively, compared to other treatments. However, it was observed that the increased application of elemental S may inhibit the availability of $\mathrm{Pb}$ translocation from soil-to-root and root-to-shoot. The study suggests that viable application of $25 \mathrm{mmol} \mathrm{EDTA} / \mathrm{kg}, 300 \mathrm{mmol} \mathrm{N} / \mathrm{kg}$ and $20 \mathrm{mmol}$ $\mathrm{S} / \mathrm{kg}$ soil have the potential to be used for soil amendment with Vetiver grass growing under contaminated mixed $\mathrm{Cd}-$ $\mathrm{Pb}$ soil conditions.
\end{abstract}

Keywords Mixed contamination - Soil amendment · EDTA · Elemental S · N-fertilizer · Vetiver grass

Any opinions, findings, conclusions or recommendations expressed in this material are those of the author(s) and do not necessarily reflect the views of the Malaysia Toray Science Foundation.

Chuck Chuan Ng

chuckz89@gmail.com

1 Faculty of Science, Institute of Biological Sciences, University of Malaya, Kuala Lumpur, Malaysia

2 Department of Plant Agriculture, Ontario Agricultural College, University of Guelph, Ontario, Canada

3 Faculty of Science, Chemistry Department, University of Malaya, Kuala Lumpur, Malaysia
Soil contamination has become an increasingly important environmental issue in both developed and developing nations. In most cases, soil contamination has been brought about by anthropogenic factors, with humans being the culprit, continuously contaminating the soil in the past and present via industrial and domestic activities. Of these, heavy metal contamination is one of the major types of inorganic soil contamination in the environment. The major contributing factors to anthropogenic heavy metal contamination in soils and the environment include the improper management of agricultural leaching, metalliferous mining and smelting, disposal of metallurgical and electronic commodities, sewage sludge and other chemical manufacturing waste materials (Bradl 2005; Alloway 2013).

Many remediation technologies, such as landfilling, soil washing, bioleaching and excavation have been attempted to resolve soils with contaminated heavy metals. However, all of these strategies are not cost-effective, extremely complicated and are not economically viable in addition to being intrusive to the environment. As a consequence, phytoremediation has emerged to be the green plant based cleanup solution that is able to remove, metabolize and degrade a wide range of hazardous soil heavy metal contaminants with minimum cost required and are non-destructive to the natural ecosystem (Ali et al. 2013). Numerous plants have being studied over the years, with reports suggesting Vetiver grass, Vetiveria zizanioides (Linn.) Nash to be one of the most promising plants, with a fast growth rate, and the ability to adapt to many environmental conditions and stress, in addition to being able to tolerate a wide range of extreme heavy metal contamination in soils (Truong et al. 2008; Truong and Danh 2015; Ng et al. 2016a).

Recent studies by Chen et al. (2012), Prasad et al. (2014) and Singh et al. (2015) have solely focused on the phytoassessment of a single metal accumulation. However, there 
is a growing concern on mixed $(\mathrm{Cd}-\mathrm{Pb})$ metal contamination with Vetiver grass, which remain unstudied and require urgent clarification. Both $\mathrm{Pb}$ and $\mathrm{Cd}$ metals are extremely toxic even at low concentration levels and humans can be easily exposed to these heavy metals through direct inhalation or ingestion of soil and dust, or consumption of contaminated plants, which can substantially affect human health and well-being (Nagajyoti et al. 2010; Ng et al. 2016b). In order to increase the metal accumulation, low cost soil amendments have been used to enhance the phyto-availability of mixed metal uptakes in Vetiver grass (US EPA 2007a; Karami et al. 2011). This study aims to evaluate the trends and effects of heavy metal accumulation and assess the influence and capability of different types and levels of low cost soil amendments to enhance the accumulation of heavy metals by Vetiver grass grown in mixed $\mathrm{Cd}-\mathrm{Pb}$ contaminated soil conditions.

\section{Materials and Methods}

The experiments were conducted in the plant house located at Rimba Ilmu, Institute of Biological Sciences, Faculty of Science, University of Malaya, Kuala Lumpur using pot assays under natural ambient lighting conditions with the average 12-h photoperiod and room temperature ranging between 25.5 and $33.5^{\circ} \mathrm{C}$ throughout the day. Top soil ( $0-20 \mathrm{~cm}$ depth) for planting was taken from a field situated at the reading of $3^{\circ} 7^{\prime} \mathrm{N}$ latitude and $101^{\circ} 39^{\prime} \mathrm{E}$ longitude and was air-dried for a week before being thoroughly mixed and sieved through $<4 \mathrm{~mm}$ mesh to remove all non-soil particles to obtain a homogenous soil sample. The soil samples underwent a preliminary physico-chemical soil assessment (Table 1) prior to the preparation of soils with mixed-contamination of $\mathrm{Cd}$ $(50 \mathrm{mg} / \mathrm{kg})$ and $\mathrm{Pb}(100 \mathrm{mg} / \mathrm{kg})$, taking into consideration both national (DOE 2009) and international (CCME 1999a, b) permissible soil heavy metals contamination guidelines. The mixed $\mathrm{Cd}-\mathrm{Pb}$ contamination was artificially spiked using cadmium nitrate tetrahydrate, $\mathrm{Cd}\left(\mathrm{NO}_{3}\right)_{2} \cdot 4 \mathrm{H}_{2} \mathrm{O}$ and lead(II) nitrate, $\mathrm{Pb}\left(\mathrm{NO}_{3}\right)_{2}$ salt compounds before being filled up with two kilograms of soil in plastic pots with height and diameter measurements of $0.18 \times 0.16 \mathrm{~m}$, respectively for all treatments. Fresh and healthy 2 -week old Vetiver seedlings were collected and placed under different individual experiments, conducted with various types of soil amendments such as disodium ethylene-diamine-tetra-acetate, $\mathrm{C}_{10} \mathrm{H}_{14} \mathrm{~N}_{2} \mathrm{Na}_{2} \mathrm{O}_{8} \cdot 2 \mathrm{H}_{2} \mathrm{O}$ (EDTA), elemental sulfur, $\mathrm{S}_{8}(\mathrm{~S})$ and ammonium nitrate, $\mathrm{NH}_{4} \mathrm{NO}_{3}$ (N-fertilizer). Four levels of $\operatorname{EDTA}(1,5,10$ and $25 \mathrm{mmol} \mathrm{EDTA} / \mathrm{kg}$ soil), five levels of elemental S (5, 10, 20, 40 and $80 \mathrm{mmol} \mathrm{S} / \mathrm{kg}$ soil) and six levels of N-fertilizer $(10,25,50,100,200$ and $300 \mathrm{mmol} \mathrm{N} /$
Table 1 Physico-chemical properties of growth media soil

\begin{tabular}{ll}
\hline Parameter (Unit) & Result \\
\hline Soil texture & \\
Sand (\%) & 93.12 \\
Very coarse sand (\%) & 1.54 \\
Coarse sand (\%) & 45.21 \\
Medium coarse sand (\%) & 21.87 \\
Fine sand (\%) & 17.58 \\
Very fine sand (\%) & 6.92 \\
Silt $(\%)$ & 4.89 \\
Clay $(\%)$ & 1.99 \\
Bulk density $\left(\mathrm{g} / \mathrm{cm}{ }^{3}\right)$ & $1.34 \pm 0.47$ \\
Porosity $(\%)$ & $49.43 \pm 3.45$ \\
Colour (Munsell colour charts) & Dull reddish \\
& brown \\
Water content $(\%)$ & $2.5 \mathrm{YR} 5 / 4$ \\
Field capacity $(\%)$ & $5.85 \pm 1.09$ \\
Saturation level $(\%)$ & $38.59 \pm 8.28$ \\
pH & $15.16(\mathrm{Dry})$ \\
Temperature $\left({ }^{\circ} \mathrm{C}\right)$ & $5.11 \pm 0.05$ \\
Metal contents $(\mathrm{mg} / \mathrm{kg})$ & $29.27 \pm 0.45$ \\
Cd & \\
Pb & $1.59 \pm 0.15$ \\
& $52.30 \pm 2.77$ \\
\hline
\end{tabular}

Mean \pm standard deviation

Table 2 Soil amendment with treatment variables

\begin{tabular}{ll}
\hline Treatment & $\begin{array}{l}\text { Description of } \mathrm{Cd} \text { and } \mathrm{Pb}(\mathrm{mg} / \mathrm{kg} \\
\text { soil), EDTA, elemental S and N } \\
(\mathrm{mmol} / \mathrm{kg} \text { soil })\end{array}$ \\
\hline Control & $50 \mathrm{Cd}+100 \mathrm{~Pb}$ \\
1 EDTA & $50 \mathrm{Cd}+100 \mathrm{~Pb}+1$ EDTA \\
5 EDTA & $50 \mathrm{Cd}+100 \mathrm{~Pb}+5$ EDTA \\
$10 \mathrm{EDTA}$ & $50 \mathrm{Cd}+100 \mathrm{~Pb}+10$ EDTA \\
$25 \mathrm{EDTA}$ & $50 \mathrm{Cd}+100 \mathrm{~Pb}+25$ EDTA \\
$5 \mathrm{~S}$ & $50 \mathrm{Cd}+100 \mathrm{~Pb}+5$ elemental S \\
$10 \mathrm{~S}$ & $50 \mathrm{Cd}+100 \mathrm{~Pb}+10$ elemental S \\
$20 \mathrm{~S}$ & $50 \mathrm{Cd}+100 \mathrm{~Pb}+20$ elemental S \\
$40 \mathrm{~S}$ & $50 \mathrm{Cd}+100 \mathrm{~Pb}+40$ elemental S \\
$80 \mathrm{~S}$ & $50 \mathrm{Cd}+100 \mathrm{~Pb}+80$ elemental S \\
$10 \mathrm{~N}$ & $50 \mathrm{Cd}+100 \mathrm{~Pb}+10 \mathrm{~N}$-fertilizer \\
$25 \mathrm{~N}$ & $50 \mathrm{Cd}+100 \mathrm{~Pb}+25 \mathrm{~N}$-fertilizer \\
$50 \mathrm{~N}$ & $50 \mathrm{Cd}+100 \mathrm{~Pb}+50 \mathrm{~N}$-fertilizer \\
$100 \mathrm{~N}$ & $50 \mathrm{Cd}+100 \mathrm{~Pb}+100 \mathrm{~N}$-fertilizer \\
$200 \mathrm{~N}$ & $50 \mathrm{Cd}+100 \mathrm{~Pb}+200 \mathrm{~N}$-fertilizer \\
$300 \mathrm{~N}$ & $50 \mathrm{Cd}+100 \mathrm{~Pb}+300 \mathrm{~N}$-fertilizer \\
&
\end{tabular}


Table 3 Operating parameters of flame atomic absorption spectrometer (FAAS) and concentrations of certified reference material (CRM) and rate of metal recovery $(\%)$ for $\mathrm{Cd}$ and $\mathrm{Pb}$

\begin{tabular}{lll}
\hline Characteristic (Unit) & $\mathrm{Cd}$ & $\mathrm{Pb}$ \\
\hline Operating parameters & & \\
Wavelength (nm) & 228.80 & 283.31 \\
Slit width (nm) & 1.35 & 1.05 \\
Air flow (L/min) & 10.00 & 10.00 \\
Acetylene flow (L/min) & 2.50 & 2.50 \\
Limit of detection (mg/kg) & 0.01 & 0.10 \\
Precision control & & \\
Initial soil (mg/kg) & $1.59 \pm 0.15$ & $52.30 \pm 2.77$ \\
Spiked metal (mg/kg) & $52.14 \pm 7.56$ & $101.88 \pm 13.21$ \\
CRM $(\mathrm{mg} / \mathrm{kg})$ & $4.04 \pm 0.22$ & $204.0 \pm 6.00$ \\
Calculated (mg $/ \mathrm{kg})$ & $3.64 \pm 1.45$ & $217.32 \pm 14.32$ \\
Metal recovery $(\%)$ & 90.09 & 106.53 \\
\hline
\end{tabular}

${ }^{a}$ BAM Germany certified reference material BRM\#12-mixed sandy soil; Mean \pm standard deviation

$\mathrm{kg}$ soil) were tested, respectively (Table 2 ). All soil amendments and heavy metal salt compounds were prepared using the products purchased from the R\&M Chemicals. All of the treatments were watered evenly with $50 \mathrm{~mL}$ of tap water once a day and their growth performance was continuously monitored throughout the 60-day period of the experiment. The study was conducted under the completely randomized design (CRD) with three replications.

Freshly harvested Vetiver were brought into the laboratory and washed in running filtered water followed by deionized water to remove any adhering soil particles before separating them into roots and shoots (tillers). The fresh weights of plant samples were determined before the samples were oven-dried for $72 \mathrm{~h}$ at $70^{\circ} \mathrm{C}$ until it achieved a constant weight. Then the dry matter yield of the Vetiver samples was determined before it was homogenized in a mortar and pestle. Approximately $0.5 \mathrm{~g}$ of the homogenized dried root and shoot samples underwent acid digestion with hydrochloric acid $(\mathrm{HCl})$, hydrogen peroxide $\left(\mathrm{H}_{2} \mathrm{O}_{2}\right)$ and nitric acid $\left(\mathrm{HNO}_{3}\right)$ as according to Method 3050B (US EPA 1996) followed by Method 7000B (US EPA 2007b) for the elemental analysis using the Perkin-Elmer AAnalyst 400 flame atomic absorption spectrometer (FAAS). The Bundesanstalt für Materialforschung und -prüfung (BAM): German Federal Institute for Materials Research and Testing, certified reference material (BRM\#12-mixed sandy soil)
Table 4 Dry matter yield $\left(\mathrm{g} / \mathrm{m}^{2}\right)$, root-shoot $(\mathrm{R} / \mathrm{S})$ ratio and tolerance index (TI) of Vetiver grass as influenced by different treatments of soil amendments

\begin{tabular}{|c|c|c|c|c|c|}
\hline \multirow[t]{2}{*}{ Treatment } & \multicolumn{3}{|c|}{ Dry matter yield $\left(\mathrm{g} / \mathrm{m}^{2}\right)$} & \multirow[t]{2}{*}{$\mathrm{R} / \mathrm{S}$ ratio } & \multirow{2}{*}{$\begin{array}{l}\text { Toler- } \\
\text { ance } \\
\text { Index } \\
\text { (TI) }\end{array}$} \\
\hline & Root & Shoot & Total & & \\
\hline \multicolumn{6}{|l|}{ EDTA } \\
\hline Control & $3.07 \pm 0.16 \mathrm{ab}$ & $4.92 \pm 0.75 \mathrm{ab}$ & $7.99 \pm 0.66 \mathrm{ab}$ & $0.624 \mathrm{ab}$ & \\
\hline 1EDTA & $3.23 \pm 0.36 \mathrm{ab}$ & $4.83 \pm 0.13 \mathrm{ab}$ & $8.07 \pm 0.31 \mathrm{ab}$ & $0.669 a b$ & $1.010 \mathrm{ab}$ \\
\hline 5EDTA & $3.29 \pm 0.28 \mathrm{ab}$ & $4.19 \pm 0.36 \mathrm{ab}$ & $7.48 \pm 0.30 \mathrm{ab}$ & $0.785 \mathrm{a}$ & $0.936 \mathrm{ab}$ \\
\hline 10EDTA & $3.57 \pm 0.21 \mathrm{a}$ & $4.75 \pm 0.24 \mathrm{ab}$ & $8.32 \pm 0.16 \mathrm{ab}$ & $0.752 \mathrm{ab}$ & $1.041 \mathrm{ab}$ \\
\hline 25EDTA & $3.45 \pm 0.35 \mathrm{ab}$ & $5.12 \pm 0.52 \mathrm{a}$ & $8.57 \pm 0.86 \mathrm{a}$ & $0.674 \mathrm{ab}$ & $1.073 \mathrm{a}$ \\
\hline \multicolumn{6}{|c|}{ Elemental S } \\
\hline Control & $3.07 \pm 0.16 \mathrm{a}$ & $4.92 \pm 0.75 \mathrm{a}$ & $7.99 \pm 0.66 \mathrm{a}$ & $0.624 \mathrm{a}$ & \\
\hline $5 \mathrm{~S}$ & $3.20 \pm 0.36 \mathrm{a}$ & $4.35 \pm 0.58 \mathrm{a}$ & $7.54 \pm 0.93 \mathrm{a}$ & $0.736 \mathrm{a}$ & $0.944 \mathrm{a}$ \\
\hline $10 \mathrm{~S}$ & $3.79 \pm 0.63 \mathrm{a}$ & $4.66 \pm 0.75 \mathrm{a}$ & $8.45 \pm 1.31 \mathrm{a}$ & $0.813 \mathrm{a}$ & $1.058 \mathrm{a}$ \\
\hline $20 \mathrm{~S}$ & $3.68 \pm 0.80 \mathrm{a}$ & $4.77 \pm 1.11 \mathrm{a}$ & $8.46 \pm 1.81 \mathrm{a}$ & $0.771 \mathrm{a}$ & $1.059 \mathrm{a}$ \\
\hline $40 \mathrm{~S}$ & $4.58 \pm 1.37 \mathrm{a}$ & $5.53 \pm 2.03 \mathrm{a}$ & $10.11 \pm 3.39 \mathrm{a}$ & $0.828 \mathrm{a}$ & $1.265 \mathrm{a}$ \\
\hline $80 \mathrm{~S}$ & $4.15 \pm 0.69 \mathrm{a}$ & $5.34 \pm 0.55 \mathrm{a}$ & $9.48 \pm 1.09 \mathrm{a}$ & $0.777 \mathrm{a}$ & $1.186 \mathrm{a}$ \\
\hline \multicolumn{6}{|l|}{$\mathrm{N}$-fertilizer } \\
\hline Control & $3.07 \pm 0.16 \mathrm{ab}$ & $4.92 \pm 0.75 \mathrm{ab}$ & 7. $99 \pm 0.66 \mathrm{a}$ & $0.624 \mathrm{a}$ & \\
\hline $10 \mathrm{~N}$ & $3.73 \pm 0.46 a b$ & $4.88 \pm 1.40 \mathrm{ab}$ & $8.61 \pm 0.98 \mathrm{a}$ & $0.764 \mathrm{a}$ & $1.078 \mathrm{a}$ \\
\hline $25 \mathrm{~N}$ & $2.63 \pm 1.16 b$ & $3.75 \pm 1.48 b$ & $6.38 \pm 2.60 \mathrm{a}$ & $0.701 \mathrm{a}$ & $0.798 \mathrm{a}$ \\
\hline $50 \mathrm{~N}$ & $3.02 \pm 0.12 \mathrm{ab}$ & $4.97 \pm 2.02 \mathrm{ab}$ & $7.99 \pm 1.93 \mathrm{a}$ & $0.608 \mathrm{a}$ & $1.000 \mathrm{a}$ \\
\hline $100 \mathrm{~N}$ & $4.28 \pm 0.79 \mathrm{a}$ & $5.07 \pm 1.06 \mathrm{a}$ & $9.35 \pm 1.62 \mathrm{a}$ & $0.844 \mathrm{a}$ & $1.170 \mathrm{a}$ \\
\hline $200 \mathrm{~N}$ & $3.89 \pm 0.17 \mathrm{ab}$ & $4.45 \pm 0.79 \mathrm{ab}$ & $8.34 \pm 0.91 \mathrm{a}$ & $0.874 \mathrm{a}$ & $1.044 \mathrm{a}$ \\
\hline $300 \mathrm{~N}$ & $2.86 \pm 0.52 b$ & $4.11 \pm 1.39 \mathrm{~b}$ & $6.97 \pm 1.82 \mathrm{a}$ & $0.696 \mathrm{a}$ & $0.872 \mathrm{a}$ \\
\hline
\end{tabular}

Mean \pm standard deviations followed by the same letters are not significantly different for each treatment means at 0.05 levels of probability 
Table 5 Metal accumulation of cadmium $(\mathrm{Cd})$ and lead $(\mathrm{Pb})$ in the root and shoot of Vetiver grass as influenced by different treatments of soil amendments

\begin{tabular}{|c|c|c|c|c|c|c|}
\hline \multirow[t]{2}{*}{ Treatment } & \multicolumn{3}{|l|}{$\mathrm{Cd}(\mathrm{mg} / \mathrm{kg})$} & \multicolumn{3}{|l|}{$\mathrm{Pb}(\mathrm{mg} / \mathrm{kg})$} \\
\hline & Root & Shoot & Total & Root & Shoot & Total \\
\hline \multicolumn{7}{|l|}{ EDTA } \\
\hline Control & $153.6 \pm 6.1 \mathrm{ab}$ & $73.4 \pm 7.6 \mathrm{~cd}$ & $227.0 \pm 1.6 \mathrm{~cd}$ & $165.8 \pm 14.0 \mathrm{a}$ & $35.5 \pm 0.6 \mathrm{~d}$ & $201.3 \pm 14.6 \mathrm{~b}$ \\
\hline 1EDTA & $133.3 \pm 6.0 \mathrm{bcd}$ & $79.2 \pm 1.1 \mathrm{~cd}$ & $212.5 \pm 4.9 \mathrm{~d}$ & $80.4 \pm 9.0 \mathrm{bc}$ & $36.2 \pm 0.9 \mathrm{~d}$ & $116.6 \pm 10.0 \mathrm{c}$ \\
\hline 5EDTA & $175.5 \pm 6.3 \mathrm{a}$ & $91.2 \pm 8.3 \mathrm{c}$ & $266.7 \pm 14.6 \mathrm{abc}$ & $65.8 \pm 4.4 \mathrm{c}$ & $74.1 \pm 2.1 \mathrm{c}$ & $139.9 \pm 6.5 \mathrm{c}$ \\
\hline 10EDTA & $147.4 \pm 16.7 \mathrm{abc}$ & $156.4 \pm 10.6 \mathrm{~b}$ & $303.8 \pm 27.3 \mathrm{a}$ & $82.5 \pm 2.6 \mathrm{bc}$ & $126.7 \pm 4.8 b$ & $209.2 \pm 7.4 \mathrm{~b}$ \\
\hline 25EDTA & $111.5 \pm 11.8 \mathrm{~cd}$ & $191.8 \pm 1.9 \mathrm{a}$ & $303.3 \pm 9.9 \mathrm{ab}$ & $93.2 \pm 7.1 \mathrm{~b}$ & $211.3 \pm 12.0 \mathrm{a}$ & $304.5 \pm 19.1 \mathrm{a}$ \\
\hline \multicolumn{7}{|l|}{ Elemental S } \\
\hline Control & $153.6 \pm 6.1 \mathrm{a}$ & $73.4 \pm 7.6 \mathrm{c}$ & $227.0 \pm 1.6 \mathrm{abcd}$ & $165.8 \pm 14.0 \mathrm{a}$ & $35.5 \pm 0.6 \mathrm{a}$ & $201.3 \pm 14.6 \mathrm{a}$ \\
\hline $5 \mathrm{~S}$ & $149.7 \pm 8.0 \mathrm{ab}$ & $129.2 \pm 10.7 \mathrm{abc}$ & $278.9 \pm 18.7 \mathrm{a}$ & $118.6 \pm 10.6 \mathrm{bc}$ & $24.3 \pm 4.2 \mathrm{bc}$ & $142.9 \pm 14.8 b$ \\
\hline $10 \mathrm{~S}$ & $109.8 \pm 6.0 \mathrm{c}$ & $144.8 \pm 32.9 \mathrm{ab}$ & $254.6 \pm 26.9 \mathrm{ab}$ & $77.5 \pm 3.3 \mathrm{~d}$ & $16.7 \pm 1.3 \mathrm{~cd}$ & $94.2 \pm 2.0 \mathrm{c}$ \\
\hline $20 \mathrm{~S}$ & $93.2 \pm 18.9 \mathrm{~cd}$ & $159.3 \pm 16.2 \mathrm{a}$ & $252.5 \pm 35.1 \mathrm{abc}$ & $121.1 \pm 10.0 \mathrm{~b}$ & $25.7 \pm 3.5 b$ & $146.8 \pm 13.5 b$ \\
\hline $40 \mathrm{~S}$ & $75.6 \pm 1.1 \mathrm{~d}$ & $97.8 \pm 15.0 \mathrm{abc}$ & $173.4 \pm 16.1 \mathrm{~d}$ & $62.8 \pm 3.0 \mathrm{~d}$ & $11.1 \pm 1.5 \mathrm{de}$ & $73.9 \pm 1.5 \mathrm{c}$ \\
\hline $80 \mathrm{~S}$ & $82.85 \pm 7.0 \mathrm{~cd}$ & $89.3 \pm 8.3 \mathrm{bc}$ & $172.2 \pm 15.4 \mathrm{~d}$ & $89.0 \pm 6.7 \mathrm{~cd}$ & $5.2 \pm 0.3 \mathrm{e}$ & $94.2 \pm 6.4 \mathrm{c}$ \\
\hline \multicolumn{7}{|l|}{$\mathrm{N}$-fertilizer } \\
\hline Control & $153.6 \pm 6.1 \mathrm{a}$ & $73.4 \pm 7.6 \mathrm{~d}$ & $227.0 \pm 1.6 \mathrm{a}$ & $165.8 \pm 14.0 \mathrm{a}$ & $35.5 \pm 0.6 \mathrm{e}$ & $201.3 \pm 14.6 \mathrm{bc}$ \\
\hline $10 \mathrm{~N}$ & $140.3 \pm 5.2 \mathrm{ab}$ & $79.6 \pm 10.0 \mathrm{~d}$ & $219.9 \pm 15.2 \mathrm{a}$ & $99.7 \pm 5.1 \mathrm{bc}$ & $187.3 \pm 12.0 \mathrm{a}$ & $286.9 \pm 17.1 \mathrm{a}$ \\
\hline $25 \mathrm{~N}$ & $129.9 \pm 20.8 \mathrm{abc}$ & $93.7 \pm 7.4 \mathrm{bcd}$ & $223.6 \pm 28.2 \mathrm{a}$ & $114.0 \pm 14.4 \mathrm{~b}$ & $163.8 \pm 20.0 \mathrm{ab}$ & $277.8 \pm 5.6 \mathrm{a}$ \\
\hline $50 \mathrm{~N}$ & $109.4 \pm 10.0 \mathrm{bcd}$ & $116.9 \pm 13.4 \mathrm{abcd}$ & $226.3 \pm 3.4 \mathrm{a}$ & $84.5 \pm 7.3 \mathrm{bcd}$ & $135.6 \pm 7.0 \mathrm{bc}$ & $220.1 \pm 14.3 b$ \\
\hline $100 \mathrm{~N}$ & $114.7 \pm 6.1 \mathrm{bcd}$ & $127.3 \pm 16.6 \mathrm{abc}$ & $242.0 \pm 22.7 \mathrm{a}$ & $63.9 \pm 3.0 \mathrm{de}$ & $102.6 \pm 8.1 \mathrm{~cd}$ & $166.5 \pm 11.0 \mathrm{c}$ \\
\hline $200 \mathrm{~N}$ & $96.5 \pm 5.4 \mathrm{cde}$ & $138.1 \pm 25.2 \mathrm{ab}$ & $234.6 \pm 30.6 \mathrm{a}$ & $82.9 \pm 8.0 \mathrm{~cd}$ & $78.4 \pm 8.0 \mathrm{~d}$ & $161.3 \pm 16.0 \mathrm{c}$ \\
\hline $300 \mathrm{~N}$ & $68.9 \pm 9.1 \mathrm{e}$ & $147.9 \pm 5.6 \mathrm{a}$ & $216.8 \pm 3.5 \mathrm{a}$ & $38.4 \pm 3.7 \mathrm{e}$ & $71.1 \pm 4.1 \mathrm{~d}$ & $109.5 \pm 0.4 \mathrm{~d}$ \\
\hline
\end{tabular}

Mean followed by the same letters are not significantly different for each treatment means at 0.05 levels of probability

was used to validate the precision of the chemical analysis technique whilst the limits of detection and metal recovery rates are recorded in Table 3. Soil samples were also airdried for $72 \mathrm{~h}$ until it reached a constant weight before it was analysed following similar analytical procedures.

The growth performance of Vetiver grass was measured using tolerance index (TI) and root-shoot (R/S) ratio. The ability for heavy metal accumulation and translocation upwards in Vetiver were evaluated by assessing the biological concentration factor (BCF), biological accumulation coefficient (BAC), translocation factor (TF) and metal uptake efficacy as follow:

$\mathrm{TI}=$ Total dry matter yield in heavy metal treatment/ total dry matter yield in control;

$\mathrm{R} / \mathrm{S}$ ratio $=$ Dry matter yield in root $/$ dry matter yield in shoot;

$\mathrm{BCF}=$ Heavy metal concentration in root/heavy metal concentration in soil;

$\mathrm{BAC}=$ Heavy metal concentration in shoot/heavy metal concentration in soil;

$\mathrm{TF}=$ Heavy metal concentration in shoot/heavy metal concentration in root; and
Metal uptake efficacy $(\%)=($ Heavy metal concentration in shoot/total heavy metal concentration removed from the soil) $\times 100 \%$

Data was analysed by performing one-way analysis of variance (ANOVA) to evaluate the growth performance and metal accumulation in Vetiver growing under different types and levels of treatments. Further statistical validity test for significant differences among treatment means, was carried out using Fisher's least significant difference (LSD) tests at the $95 \%$ level of confidence whilst linear regression analysis was undertaken to assess the relationships between the different types of soil amendments and the accumulation of heavy metal concentration in Vetiver grass.

\section{Results and Discussion}

The dry matter yields were not affected by treatment variables (Table 4) as there were no significant differences $(p>0.05)$ found in all of the three different types and levels of soil amendments. These findings indicate that the 
Table 6 Metal accumulation of cadmium $(\mathrm{Cd})$ and lead $(\mathrm{Pb})$ in its biological concentration factor (BCF), biological accumulation coefficient (BAC), translocation factor (TF) and metal uptake efficacy (\%) of Vetiver grasses as influenced by different treatments of soil amendments

\begin{tabular}{|c|c|c|c|c|c|c|c|c|}
\hline \multirow[t]{2}{*}{ Treatment } & \multicolumn{4}{|c|}{ Cd accumulation } & \multicolumn{4}{|c|}{$\mathrm{Pb}$ accumulation } \\
\hline & $\mathrm{BCF}$ & $\mathrm{BAC}$ & $\mathrm{TF}$ & Efficacy (\%) & $\mathrm{BCF}$ & BAC & $\mathrm{TF}$ & $\begin{array}{l}\text { Efficacy } \\
(\%)\end{array}$ \\
\hline \multicolumn{9}{|l|}{ EDTA } \\
\hline Control & $3.072 \mathrm{ab}$ & $1.468 \mathrm{c}$ & $0.4778 \mathrm{c}$ & $32.33 \mathrm{c}$ & $1.658 \mathrm{a}$ & $0.355 \mathrm{~d}$ & $0.214 \mathrm{e}$ & $17.64 \mathrm{e}$ \\
\hline 1EDTA & $2.665 \mathrm{bc}$ & $1.584 \mathrm{c}$ & $0.594 \mathrm{c}$ & $37.28 \mathrm{c}$ & $0.804 \mathrm{~b}$ & $0.362 \mathrm{~d}$ & $0.451 \mathrm{~d}$ & $31.06 \mathrm{~d}$ \\
\hline 5EDTA & $3.510 \mathrm{a}$ & $1.824 \mathrm{c}$ & $0.520 \mathrm{c}$ & $34.20 \mathrm{c}$ & $0.658 \mathrm{~b}$ & $0.741 \mathrm{c}$ & $1.126 \mathrm{c}$ & $52.97 \mathrm{c}$ \\
\hline 10EDTA & $2.948 a b c$ & $3.128 \mathrm{~b}$ & $1.061 \mathrm{~b}$ & $51.48 \mathrm{~b}$ & $0.825 \mathrm{~b}$ & $1.267 \mathrm{~b}$ & $1.536 \mathrm{~b}$ & $60.56 \mathrm{~b}$ \\
\hline 25EDTA & $2.229 \mathrm{c}$ & $3.836 \mathrm{a}$ & $1.721 \mathrm{a}$ & $63.25 \mathrm{a}$ & $0.932 \mathrm{~b}$ & $2.113 \mathrm{a}$ & $2.268 \mathrm{a}$ & $69.40 \mathrm{a}$ \\
\hline \multicolumn{9}{|l|}{ Elemental S } \\
\hline Control & $3.072 \mathrm{a}$ & $1.468 \mathrm{c}$ & $0.4778 \mathrm{c}$ & $32.33 \mathrm{c}$ & $1.658 \mathrm{a}$ & $0.355 \mathrm{a}$ & $0.214 \mathrm{a}$ & $17.64 \mathrm{a}$ \\
\hline $5 \mathrm{~S}$ & $2.994 \mathrm{a}$ & $2.583 \mathrm{abc}$ & $0.863 \mathrm{bc}$ & $46.32 \mathrm{~b}$ & $1.186 \mathrm{bc}$ & $0.243 \mathrm{bc}$ & $0.205 \mathrm{a}$ & $17.01 \mathrm{a}$ \\
\hline $10 \mathrm{~S}$ & $2.195 \mathrm{~b}$ & $2.895 \mathrm{ab}$ & $1.319 \mathrm{ab}$ & $56.88 \mathrm{ab}$ & $0.775 \mathrm{c}$ & $0.167 \mathrm{~cd}$ & $0.215 \mathrm{a}$ & $17.68 \mathrm{a}$ \\
\hline $20 \mathrm{~S}$ & $1.864 \mathrm{~b}$ & $3.186 \mathrm{a}$ & $1.709 \mathrm{a}$ & $63.09 \mathrm{a}$ & $1.211 \mathrm{~b}$ & $0.257 \mathrm{~b}$ & $0.212 \mathrm{a}$ & $17.51 \mathrm{a}$ \\
\hline $40 \mathrm{~S}$ & $1.511 \mathrm{~b}$ & $1.956 \mathrm{bc}$ & $1.295 \mathrm{ab}$ & $56.42 \mathrm{ab}$ & $0.628 \mathrm{c}$ & $0.111 \mathrm{de}$ & $0.177 \mathrm{a}$ & $15.03 \mathrm{a}$ \\
\hline $80 \mathrm{~S}$ & $1.657 \mathrm{~b}$ & $1.786 \mathrm{bc}$ & $1.078 \mathrm{bc}$ & $51.87 \mathrm{ab}$ & $0.890 \mathrm{c}$ & $0.051 \mathrm{e}$ & $0.058 \mathrm{~b}$ & $5.46 \mathrm{~b}$ \\
\hline \multicolumn{9}{|l|}{$\mathrm{N}$-fertilizer } \\
\hline Control & $3.072 \mathrm{a}$ & $1.468 \mathrm{~d}$ & $0.478 \mathrm{c}$ & $32.33 \mathrm{e}$ & $1.658 \mathrm{a}$ & $0.355 \mathrm{e}$ & $0.214 \mathrm{~d}$ & $17.64 \mathrm{~d}$ \\
\hline $10 \mathrm{~N}$ & $2.806 \mathrm{ab}$ & $1.592 \mathrm{~d}$ & $0.567 \mathrm{c}$ & $36.20 \mathrm{e}$ & $0.997 \mathrm{bc}$ & $1.873 \mathrm{a}$ & $1.880 \mathrm{ab}$ & $65.27 \mathrm{a}$ \\
\hline $25 \mathrm{~N}$ & $2.598 a b c$ & $1.874 \mathrm{bcd}$ & $0.721 \mathrm{c}$ & $41.91 \mathrm{cde}$ & $1.140 \mathrm{~b}$ & $1.638 \mathrm{ab}$ & $1.437 \mathrm{abc}$ & $58.96 \mathrm{ab}$ \\
\hline $50 \mathrm{~N}$ & $2.187 \mathrm{bcd}$ & $2.338 \mathrm{abcd}$ & $1.069 \mathrm{bc}$ & $51.67 \mathrm{bcd}$ & $0.845 \mathrm{bc}$ & $1.356 \mathrm{bc}$ & $1.605 \mathrm{ab}$ & $61.61 \mathrm{ab}$ \\
\hline $100 \mathrm{~N}$ & $2.294 \mathrm{bcd}$ & $2.546 \mathrm{abc}$ & $1.109 \mathrm{bc}$ & $52.60 \mathrm{bc}$ & $0.639 \mathrm{de}$ & $1.026 \mathrm{~cd}$ & $1.607 \mathrm{ab}$ & $61.64 \mathrm{ab}$ \\
\hline $200 \mathrm{~N}$ & $1.929 \mathrm{cde}$ & $2.762 \mathrm{ab}$ & $1.432 \mathrm{~b}$ & $58.88 \mathrm{ab}$ & $0.829 \mathrm{~cd}$ & $0.784 \mathrm{~d}$ & $0.946 \mathrm{~cd}$ & $48.62 \mathrm{c}$ \\
\hline $300 \mathrm{~N}$ & $1.378 \mathrm{e}$ & $2.958 \mathrm{a}$ & $2.147 \mathrm{a}$ & $68.22 \mathrm{a}$ & $0.384 \mathrm{e}$ & $0.711 \mathrm{e}$ & $1.854 \mathrm{a}$ & $64.96 \mathrm{ab}$ \\
\hline
\end{tabular}

Mean \pm standard deviations followed by the same letters are not significantly different for each treatment means at 0.05 levels of probability

application of mixed $\mathrm{Cd}-\mathrm{Pb}$ contamination in soil growth media may not have much effect on the overall (roots, shoots and total) dry matter yield for Vetiver grass regardless of the different types and levels of treatment combination. Subsequently, the root-shoot $(\mathrm{R} / \mathrm{S})$ ratio and tolerance index (TI) was employed to assess the capability of the Vetiver grass growing under mixed $\mathrm{Cd}-\mathrm{Pb}$ contamination conditions. Similarly, no significant differences $(p>0.05)$ was observed in the R/S ratio and tolerance index (TI) among the treatment variables. The Vetiver grass showed high tolerant and good adaptability properties to the contaminated mixed $\mathrm{Cd}-\mathrm{Pb}$ soil conditions as was previously reported in Chen et al. (2004) and Danh et al. (2009).

Metal accumulation for both $\mathrm{Cd}$ and $\mathrm{Pb}$ in the roots and shoots of Vetiver grass are shown in Table 5. Each level of EDTA, elemental S and N-fertilizer soil amended treatment recorded a distinctive $\mathrm{Cd}(172.2-303.3 \mathrm{mg} / \mathrm{kg})$ and $\mathrm{Pb}$ $(73.9-304.5 \mathrm{mg} / \mathrm{kg}$ ) concentration pattern in the roots and shoots of Vetiver. The $25 \mathrm{mmol}$ EDTA treatment exhibited the highest accumulation of both $\mathrm{Pb}(211.3 \pm 12.0 \mathrm{mg} / \mathrm{kg})$ and $\mathrm{Cd}(191.8 \pm 1.9 \mathrm{mg} / \mathrm{kg})$ in the shoots. Between roots and shoots, the accumulation of both $\mathrm{Cd}$ and $\mathrm{Pb}$ were comparatively greater in the shoots than the roots for $10 \mathrm{mmol}$
EDTA and 25 mmol EDTA. A significant increase $(p<0.05)$ in $\mathrm{Cd}$ and $\mathrm{Pb}$ accumulation in the shoots were obtained in both 10 mmol EDTA and 25 mmol EDTA treatments compared to the control. For all types and levels of soil amendments, $\mathrm{Pb}$ accumulation in the roots, together with selected Cd roots treatments $(25 \mathrm{EDTA}, 10 \mathrm{~S}, 20 \mathrm{~S}, 40 \mathrm{~S}, 80 \mathrm{~S}, 50 \mathrm{~N}$, $100 \mathrm{~N}, 200 \mathrm{~N}$ and $300 \mathrm{~N})$, a significant reduction $(p<0.05)$ was observed compared to the control. With regard to $\mathrm{Pb}$ accumulation, significantly lower $(p<0.05)$ uptake was observed in all levels of elemental $\mathrm{S}$ treatment irrespective of roots, shoots and total metal accumulation compared to the control. However, a significantly larger $(p<0.05)$ accumulation of $\mathrm{Pb}$ in the shoots was observed in all $\mathrm{N}$-fertilizer treatments compared with the control. On the other hand, no significant difference $(p>0.05)$ was found between the total metal accumulation of $\mathrm{Cd}$ in both elemental $\mathrm{S}$ and $\mathrm{N}$-fertilizer treatments compared with control.

The comparatively lower BCF values were obtained in all types of soil amended treatments compared to the control, probably due to the effects of lower accumulation of both $\mathrm{Cd}$ and $\mathrm{Pb}$ metals in the roots than shoots (Table 6). Alternatively, all levels of EDTA and N-fertilizer treatments recorded remarkably higher $\mathrm{BAC}$ and $\mathrm{TF}$ values than the 
Table 7 Regression equation, coefficients of determination $\left(\mathrm{R}^{2}\right)$ and $\mathrm{F}$ values of different parameters in Vetiver grass

\begin{tabular}{lccc}
\hline Regression equation & $\mathrm{R}^{2}$ & $\mathrm{R}$ & $\mathrm{F}$ value \\
\hline $\begin{array}{l}\text { Relationship between level of soil amendments and } \mathrm{Cd} \\
\quad \text { accumulation }\end{array}$ & & \\
$\mathrm{Y}_{\mathrm{Cd}}(\mathrm{EDTA})=239.579+3.119 \mathrm{X}_{1}$ & 0.579 & 0.761 & 2.746 \\
$\mathrm{Y}_{\mathrm{Cd}}(\mathrm{S})=271.075-1.445 \mathrm{X}_{1}$ & 0.779 & 0.882 & $10.557^{*}$ \\
$\mathrm{Y}_{\mathrm{Cd}}(\mathrm{N})=227.831-0.006 \mathrm{X}_{1}$ & 0.005 & 0.068 & 0.019
\end{tabular}

Relationship between level of soil amendments and $\mathrm{Pb}$ accumulation

$\begin{array}{lllc}\mathrm{Y}_{\mathrm{Pb}}(\mathrm{EDTA})=111.152+7.939 \mathrm{X}_{1} & 0.977 & 0.988 & 83.180^{* *} \\ \mathrm{Y}_{\mathrm{Pb}}(\mathrm{S})=127.273-0.546 \mathrm{X}_{1} & 0.261 & 0.511 & 1.061 \\ \mathrm{Y}_{\mathrm{Pb}}(\mathrm{N})=268.567-0.569 \mathrm{X}_{1} & 0.849 & 0.921 & 22.405^{* *}\end{array}$

Relationship between dry matter yield and Cd accumulation

$\begin{array}{lllc}\mathrm{Y}_{\mathrm{Cd}}(\text { EDTA })=-60.363+40.926 \mathrm{X}_{2} & 0.132 & 0.363 & 0.303 \\ \mathrm{Y}_{\mathrm{Cd}}(\mathrm{S})=646.832-47.748 \mathrm{X}_{2} & 0.915 & 0.956 & 32.185^{* *} \\ \mathrm{Y}_{\mathrm{Cd}}(\mathrm{N})=181.232+5.787 \mathrm{X}_{2} & 0.446 & 0.668 & 3.224\end{array}$

Relationship between dry matter yield and $\mathrm{Pb}$ accumulation

$\begin{array}{llll}\mathrm{Y}_{\mathrm{Pb}}(\mathrm{EDTA})=124.487+9.154 \mathrm{X}_{2} & 0.020 & 0.140 & 0.040 \\ \mathrm{Y}_{\mathrm{Pb}}(\mathrm{S})=344.732-26.610 \mathrm{X}_{2} & 0.668 & 0.817 & 6.038 \\ \mathrm{Y}_{\mathrm{Pb}}(\mathrm{N})=252.947-6.207 \mathrm{X}_{2} & 0.009 & 0.096 & 0.038\end{array}$

$X_{1}$ level of soil amendments, $X_{2}$ dry matter yield

*Significant at 0.05 level of probability

**Significant at 0.01 level of probability

control in both $\mathrm{Cd}$ and $\mathrm{Pb}$ accumulation, suggesting that the pathway for metal translocation from soil into shoots were more favourable. The 25 mmol EDTA treatment demonstrated the highest BAC (3.836) and TF (2.268) for $\mathrm{Cd}$ and $\mathrm{Pb}$ accumulation, respectively. Chiu et al. (2005) and Chen et al. (2012) also reported similar findings in Vetiver grass showing the accumulation of heavy metals is gradually enhanced with the application EDTA. Furthermore, the higher accumulation of heavy metals in the shoots than the roots also suggested that the shoots of Vetiver grass act as the sink for both $\mathrm{Cd}$ and $\mathrm{Pb}$ accumulation. Among the different types of soil amendments, $\mathrm{N}$-fertilizer (36.20\%-68.22\%), EDTA $(34.20 \%-63.25 \%)$ and elemental S (46.32\%-63.09\%) recorded higher accumulation efficacy for $\mathrm{Cd}$, compared with other individual levels of treatment, respectively. On the other hand, 25 mmol EDTA $(69.40 \%), 10 \mathrm{mmol} \mathrm{N}$ $(65.27 \%)$ and $300 \mathrm{mmol} \mathrm{N}(64.96 \%)$ exhibited the greatest accumulation efficacy for $\mathrm{Pb}$ with more than a two-fold increase compared to the control. However, the application of elemental $\mathrm{S}$ showed no significant difference $(p>0.05)$ in the enhancement of $\mathrm{Pb}$ accumulation regardless of the different concentrations used, compared to the control. Moreover, the efficiency of $\mathrm{Pb}$ metal translocation from soil-to-root and root-to-shoot decreased with increasing amount of elemental $\mathrm{S}$ used. These findings are contrary to that reported by Feng et al. (2009), Motior et al. (2011), Rahman et al. (2011) as well as Dede and Ozdemir (2016) which used other types of plant species. Despite the lower $\mathrm{Pb}$ accumulation in the elemental S treatments, appreciably higher BAC, TF and metal efficacy for $\mathrm{Cd}$ accumulation than the control were detected.

Generally, the inclination trend observed for $\mathrm{Cd}$ accumulation, among the different types of soil amendments were in the order of $\mathrm{N}$-fertilizer $(300 \mathrm{~N})>$ EDTA $(25 \mathrm{EDTA})>$ elemental S (20S) for all the treatments. The findings show that application of higher levels of both N-fertilizer and EDTA are likely to enhance the accumulation of $\mathrm{Cd}$ in the shoots of Vetiver grass whereas the opposite was found with elemental S. Notwithstanding, the trend for $\mathrm{Pb}$ accumulation was in the following order of EDTA (25EDTA) $>\mathrm{N}$-fertilizer $>>$ elemental $\mathrm{S}$ among all treatments. The application of higher levels of EDTA and N-fertilizer could have probably increased $\mathrm{Pb}$ accumulation in the shoots of Vetiver grass, as similar trends have been reported previously by Nascimento et al. (2006), Chiu et al. (2006) and Rahman et al. (2013). Although higher $\mathrm{Pb}$ accumulation was recorded with the application of $\mathrm{N}$-fertilizer in the shoots, relatively all levels of $\mathrm{N}$-fertilizer treatments displayed approximately similar accumulation of $\mathrm{Pb}$. With higher application levels of elemental $\mathrm{S}, \mathrm{Pb}$ accumulation are more likely to drop in both the roots and shoots of Vetiver grass.

There were strong and significant positive relationships found between the accumulations of Pb in EDTA $(r=0.998)$ and $\mathrm{N}$-fertilizer $(r=0.921)$ treatments with the levels of soil amendments used when grown under the mixed heavy metal contamination (Table 7). Elemental S treatment $(r=0.956)$ exhibited strong negative correlation with regard to dry matter yield and $\mathrm{Cd}$ accumulation due to the appreciably decreased metal uptake in the roots and shoots in selected elemental $\mathrm{S}$ treatments. The regression equations revealed a positive association with the application of EDTA showing a comparably higher influence on dry matter yield, as well as $\mathrm{Cd}$ and $\mathrm{Pb}$ accumulation compared to the other two types of soil amendments. The study demonstrates that $25 \mathrm{mmol}$ EDTA, $300 \mathrm{mmol} \mathrm{N}$-fertilizer and $20 \mathrm{mmol}$ elemental $\mathrm{S}$ are the best possible soil amendments with Vetiver grass in the mixed $\mathrm{Cd}-\mathrm{Pb}$ contaminated soil condition.

Acknowledgments This research work is made possible through funding provided by the University of Malaya, Kuala Lumpur (PG0062013A and RK001-2016) and the Malaysia Toray Science Foundation (STRG15/G251) grants.

\section{References}

Ali H, Khan E, Anwar M (2013) Phytoremediation of heavy metals: concepts and applications. Chemosphere 91(7):869-881

Alloway BJ (2013) Heavy metals in soils: trace metals and metalloids in soils and their bioavailability. (3rd ed.). Environ Pollut 22. In: Alloway BJ (ed) Sources of heavy metals and metalloids in soils. Springer, London, pp 11-50 
Bradl HB (2005) Heavy metals in the environment. In: Bradl HB (ed) Sources and origins of heavy metals, Elsevier Academic Press, pp 1-27

CCME Canadian Council of Ministers of the Environment (1999a) Canadian soil quality guidelines for the protection of environmental and human health: Canadian environmental quality guidelines - Cadmium. http://ceqg-rcqe.ccme.ca/download/en/261. Accessed Dec 2015

CCME Canadian Council of Ministers of the Environment (1999b) Canadian soil quality guidelines for the protection of environmental and human health: Canadian environmental quality guidelines-Lead. http://ceqg-rcqe.ccme.ca/download/en/269. Accessed Dec 2015

Chen Y, Shen Z, Li X (2004) The use of Vetiver grass (Vetiveria zizanioides) in the phytoremediation of soils contaminated with heavy metals. Appl Geochem 19(10):1553-1565

Chen KF, Yeh TY, Lin CF (2012) Phytoextraction of $\mathrm{Cu}, \mathrm{Zn}$ and $\mathrm{Pb}$ enhanced by chelators with Vetiver (Vetiveria zizanioides) in hydroponic and pot experiments. ISRN Ecol. doi: $10.5402 / 2012 / 729693$

Chiu KK, Ye ZH, Wong MH (2005) Enhanced uptake of As, Zn and $\mathrm{Cu}$ byVetiveria zizanioides and Zea maysusing chelating agents. Chemosphere 60(10):1365-1375

Chiu KK, Ye ZH, Wong MH (2006) Growth ofVetiveria zizanioides andPhragmities australison $\mathrm{Pb} / \mathrm{Zn}$ and $\mathrm{Cu}$ mine tailings amended with manure compost and sewage sludge: a greenhouse study. Bioresource Technol 97(1):158-170

Danh LT, Truong P, Mammucari R, Tran T, Foster N (2009) Vetiver grass (Vetiveria Zizanioides) a choice plant for phytoremediation of heavy metals and organic wastes. Int J Phytoremediat 11(8):664-691

Dede G, Ozdemir S (2016) Effects of elemental sulphur on heavy metal uptake by plants growing on municipal sewage sludge. J Environ Manage 166:103-108

DOE Department of Environment, Malaysia (2009) Contaminated land management and control guidelines no. 1: Malaysian recommended site screening levels for contaminated land. http:// www.doe.gov.my/portalv1/wp-content/uploads/ContaminatedLand-Management-and-Control-Guidelines-No-1_MalaysianRecommended-Site-Screening-Levels-for-Contaminated-Land. pdf. Accessed Dec 2015

Feng Q, Tai P, Li P, Guo Y, Fu S (2009) Role of sulfur in cadmium accumulation of Tagetes erecta L. J Plant Nutr 32(6):919-928

Karami N, Clemente R, Moreno-Jiménez E, Lepp NW, Beesley L (2011) Efficiency of green waste compost and biochar soil amendments for reducing lead and copper mobility and uptake to ryegrass. J Hazard Mater 191(1):41-48

Motior MR, Abdou AS, Al Darwish FH, El-Tarabily KA, Awad MA, Golam F, Sofian-Azirun M (2011) Influence of elemental sulfur on nutrient uptake, yield and quality of cucumber grown in sandy calcareous soil. Aust J Crop Sci 5(12):1610-1615

Nagajyoti PC, Lee KD, Sreekanth TVM (2010) Heavy metals, occurrence and toxicity for plants: a review. Environ Chem Lett 8(3):199-216

Nascimento CWA, Amarasiriwardena D, Xing B (2006) Comparison of natural organic acids and synthetic chelates at enhancing phytoextraction of metals from a multi-metal contaminated soil. Environ Pollut 140(1):114-123

Ng CC, Law SH, Amru NB, Motior MR, Radzi BM (2016a) Phytoassessment of soil heavy metal accumulation in tropical grasses. $\mathrm{J}$ Anim Plant Sci 26(3):686-696

Ng CC, Rahman MM, Boyce AN, Abas MR (2016b) Heavy metals phyto-assessment in commonly grown vegetables: water spinach (I. aquatica) and okra (A. esculentus). Springer Plus 5(1):469

Prasad A, Chand S, Kumar S, Chattopadhyay A, Patra DD (2014) Heavy metals affect yield, essential oil compound and rhizosphere microflora of Vetiver (Vetiveria zizanioides) grass. Commun Soil Sci Plan 45(11):1511-1522

Rahman MM, Soaug AA, Darwish FHA, Golam F, Sofian-Azirun M (2011) Growth and nutrient uptake of maize plants as affected by elemental sulfur and nitrogen fertilizer in sandy calcareous soil. Afr J Biotechnol 10(60):12882-12889

Rahman MM, Azirun SM, Boyce AN (2013) Enhanced accumulation of copper and lead in Amaranth (Amaranthus paniculatus), Indian Mustard (Brassica juncea) and Sunflower (Helianthus annuus). PLoS One 8(5):e62941

Singh V, Thakur L, Mondal P (2015) Removal of lead and chromium from synthetic wastewater using Vetiveria zizanioides. Clean Soil Air Water 43(4):538-543

Truong P, Danh LT (2015) The Vetiver system for improving water quality: prevention and treatment of contaminated water and land, 2nd edn. The Vetiver Network International

Truong P, Van TT, Pinners E (2008) Vetiver system applications technical reference manual, 2nd edn. The Vetiver Network International

US EPA (1996) Method 3050B Acid digestion of sediments, sludges and soils, United States Environmental Protection Agency. https://www.epa.gov/sites/production/files/2015-06/documents/ epa-3050b.pdf. Accessed Dec 2015

US EPA (2007a) The use of soil amendments for remediation revitalization and reuse. United States Environmental Protection Agency. https://www.epa.gov/sites/production/files/2015-05/ documents/the_use_of_soil_amendments_for_remediation_revitalization and reule.pdf. Accessed Dec 2015

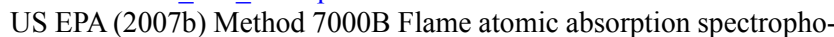
tometry, United States Environmental Protection Agency. https:// www.epa.gov/sites/production/files/2015-12/documents/7000b. pdf. Accessed Dec 2015 